Authors' pre-print version

To be published as:

Pérez Liebergesell N., Vermeersch P.W., Heylighen A., Designing for a future self:

how architect Stéphane Beel empathises with wheelchair-users, Journal of Architecture

Please refer to the final published version. 


\title{
Designing for a future self: how architect Stéphane Beel empathises with wheelchair-users
}

\author{
Natalia Pérez Liebergesell, ${ }^{\mathrm{a}}$ Peter-Willem Vermeersch, ${ }^{\mathrm{a}, \mathrm{b}}$ Ann Heylighen ${ }^{\mathrm{a}}$ \\ ${ }^{a}$ KU Leuven, Department of Architecture, Research[x]Design, 3001 Leuven, Belgium \\ ${ }^{b}$ (Full) Scale Architecten, 3010 Kessel-Lo (Leuven), Belgium \\ ORCID Natalia Pérez Liebergesell: https://orcid.org/0000-0002-5604-3697 \\ ORCID Peter-Willem Vermeersch: https://orcid.org/0000-0002-3809-444X \\ ORCID Ann Heylighen: https://orcid.org/0000-0001-6811-3464
}

\section{Acknowledgements}

We would like to thank Stéphane Beel for his time, interest, and enthusiasm. We also appreciate Piet Coessens', Robin Engels', and Laura Beel's clarifications and the sharing of relevant documents. This study received funding from the Research Fund KU Leuven in the form of a C1-project [GrantNo. C14/16/047]. The study was approved by the Social and Societal Ethics Committee of KU Leuven.

\section{Disclosure statement}

The authors declare no conflict of interest. 


\title{
Designing for a future self: how architect Stéphane Beel empathises with wheelchair-users
}

\author{
Abstract \\ Architects tend to design consistent with their own values and concerns. Designing for \\ imaginary users, especially disabled ones, may pose major challenges. Drawing on aspects \\ of focused ethnography, we show how architect Stéphane Beel's anticipation of using a \\ wheelchair in the future due to a progressive-regressive disease influences his willingness \\ and ability to empathise with, and design for, wheelchair-users. We study a museum \\ building in Belgium, that he, as part of a larger design team, helped restoring, renovating, \\ and expanding, paying special attention to (wheelchair-)accessibility. We rely on \\ interviews, observations, design documents, and two tours guided by Stéphane. Findings \\ suggest that Stéphane's ability to empathise with users benefits from flexibly using his \\ embodied self, and moving between positions in various design stages. Foregrounding \\ bodily resonances with wheelchair-users seems to facilitate incorporating the other as self \\ and reaching affect, while thinking of the self as other promotes looking at designs through \\ someone else's eyes. Empathy brought Stéphane to design inclusive environments, not \\ because he has embodied knowledge derived from using a wheelchair, or beyond his \\ technical knowledge as an architect, but because he feels affected by his own future \\ possibility. Affect, set against indifference, triggers a powerful response in his architecture.
}

Keywords: accessibility; anticipation; architecture; embodiment; empathy; wheelchair-use 


\section{Introduction}

A major challenge for architects and other designers is to design for imaginary users, especially disabled $^{1}$ ones. Designing for imaginary users requires the ability to imagine how built environments will be used and experienced by them. During the design process, however, architects tend to refer to themselves. ${ }^{2}$ Imrie ${ }^{3}$ identifies a tendency amongst architects to reduce the imaginary user 'to a mirror or self-referential image of the architect's body', and further overlook bodily diversity in 'its multiple forms of embodiment'.

Within architectural practice, ${ }^{4}$ and beyond,${ }^{5}$ an inclination exists to cleanly categorise disabled people as 'not-me'. This separation may explain why linking disability to architecture often remains limited to merely complying with accessibility codes and technical requirements, while disabled people's social, experiential, embodied, and narrative universe is overlooked. ${ }^{6}$ The term 'wheelchair-user', Suri $^{7}$ stresses, describes a person only in an abstract and limited way; 'it is hard for a designer, without personal experience of what it's like to use a wheelchair, to feel more than a reluctant obligation to follow regulations that apply'. In contrast, she explains, watching a video documentary of a wheelchair-user making a train journey 'will introduce the designer to a real person with whom they can empathise - a human being rather than a de-personalised description'.

When being or becoming disabled themselves, architects gain direct access to a kind of experience other design professionals may only empathise with at best. Previous studies on blind architects Carlos Mourão Pereira and Chris Downey, ${ }^{8}$ wheelchair-user architect Marta Bordas Eddy, ${ }^{9}$ and deaf architect George Balsley, ${ }^{10}$ examined the relationship between their embodied experiences and design practices and outcomes. These studies suggest that, whereas all four 
architects acquired embodied knowledge that helps them design inclusive environments (especially for people similar to them), they also develop an awareness that their knowledge is oftentimes not sufficient and thus draw on other people's input.

In this article we set out to extend these studies by investigating how an architect's design practice and outcomes are affected not by being disabled, but by anticipating becoming disabled in the future. To this end we focus on renowned Belgian architect Stéphane Beel, who was diagnosed with Multiple Sclerosis (MS) and expresses having become more sensitive due to his disease. ${ }^{11}$ While Stéphane himself does not explicitly use the term 'empathy' during the study, our analysis shows that it plays a role with regard to imagining end-users. Based on a case study of his design for the Koninklijk Museum voor Midden-Africa (KMMA), ${ }^{12}$ we examine how the architect's anticipation of using a wheelchair in the future - without having had the actual experience yet - affects his ability to design for others, and how the design outcome is experienced from the user perspective of a wheelchair-user. In doing so, we contribute to a nuanced understanding of empathy relevant in (architectural) design and offer insight into its potential, suitability, and limitations through a concrete, materialised example.

By way of background to our case study, the next section presents a theoretical framework to understand empathy - its relevance and limitations - in relation to design practice. Subsequently the materials and methods section provides a detailed description of how the study was conducted, after which the findings of our analysis are presented and discussed in relation to existing work. 


\section{Background}

Empathy is generally understood as the ability of putting oneself in the shoes of the other. ${ }^{13}$ The idea that empathy can reduce the gap between 'self' and (disabled) 'other' is widely recognised in (architectural) design; empathy allows designers to gain an understanding of users' concerns, including functional, emotional, aspirational, cultural, and social aspects. ${ }^{14}$ Yet, while commonly considered as a static attribute, a trait that people have, rather than something they $d o$, Marshall and Hooker ${ }^{15}$ draw attention to dynamic-performative aspects of empathy: they question what changes when people show empathy, how it shifts interactions, and what effects it produces. Furthermore, they stress that definitions of empathy or how it occurs rarely take into account embodied subjectivities of both parties (e.g. users' and architects').

Starting from an explicit link between empathy and design, Heylighen and Dong ${ }^{16}$ synthesise contemporary understandings of empathy in philosophy and cognitive science, and further describe several implications for design. Two aspects they outline are particularly relevant to our study: the presence of the other and the role of the embodied self.

\section{The Presence of the Other}

Referencing Bloom, ${ }^{17}$ Heylighen and Dong point at the importance of the other's presence as a fundamental part of empathy. Empathy, they write, is a spotlight focusing on certain people in the 'here and now'. One cannot empathise with no-body; with figures or technical information. Rather, some-body is needed to empathise with; a direct acquaintance with the other is essential. ${ }^{18}$ Within the phenomenological tradition, the other's presence is taken literally as bodily presence. This 'restricts [empathy] to face-to-face-based forms of interpersonal 
encounter', ${ }^{19}$ and thus poses a major challenge in design practice, where designers may have very little or no direct contact with whom they design for. Within cognitive science, by contrast, scholars have pointed out that one can empathise with people who are not bodily present, but rather similar or 'close' to you - figuratively. ${ }^{20}$

The act of empathising is directly linked to affective resonances: genuine empathy is characterised as 'the vicarious sharing of an affect'. ${ }^{21}$ Moreover, affect also seems to be necessary to put empathy in motion at the outset (i.e. to be motivated to empathise). Empathy requires a desire to connect with the other, a certain degree of identification and incorporation, in order to trigger an affective response (i.e. to be moved into action). In relation to design, empathy is taken to be influenced by the designer's willingness and a certain motivation to invest time: 'when designers do not see the advantages of empathy in design, the results can be unsatisfying, ${ }^{22}$

\section{The Role of the Embodied Self}

A crucial component of empathy, Heylighen and Dong point out, is an embodied relationship between self and other. Empathy results from cognitive processes making the self attribute mental states to the other: 'in empathy I participate in the other's positing'. ${ }^{23}$ The empathiser's own embodied experiences are intimately connected to their empathic understanding of the other's. The empathiser is not an invisible, neutral, or disembodied observer, but also somebody. So far, Heylighen and Dong point out, little attention has been given to the empathiser's bodily features in design practice.

Yet another role of the embodied self in empathic processes derives from the hypothesis 
that empathising presupposes a bodily commonality or overlap. ${ }^{24}$ It is more likely to be successful when parts of the self are recognisable in the other. When the gap is too big, it may be compromised: "if identification with others opens the door for empathy, the absence of identification closes that door' ${ }^{25}$ Empathy, De Waal ${ }^{26}$ further explains, is aroused by those who have been 'approved' based on similarity or the sharing of category membership. This may have significant consequences in design for those consistently categorised as distant out-group others, e.g. disabled people.

Rather than trying to empathise with these distant others' experience in its full complexity, Heylighen and Dong indicate, it may be relevant for designers to acknowledge that they can empathise only with particular aspects. In design, they further express, empathy seems to have become an ideology predominantly advanced as a quality, rather than a principle that is appropriate in some situations and inappropriate in others. Often overlooked, they conclude, is the evaluative component, where designers need to assess which users, and which aspects, they are able to empathise with.

In what remains we will examine how architect Stéphane's anticipation affects his design practice and the role of empathy therein.

\section{Materials and Methods}

Given our aim to gain insight into how anticipating becoming disabled affects an architect's design practice, we adopted a qualitative research approach. ${ }^{27}$ As mentioned, we chose as focus of our single case study the KMMA in Tervuren, Belgium, where Stéphane collaborated in. 
The connection Stéphane himself made between anticipating using a wheelchair due to his disease and how it impacts the design of the KMMA triggered us to investigate this interaction in detail. With Stéphane and the KMMA, we selected a unique and information-rich case, rather than a representative one. Our aim is not to generalize through our findings, but to relate the insights gained to existing literature and/or prevailing frames of reference. ${ }^{28}$

Stéphane developed the KMMA collaboratively with a larger design team and multiple collaborations. The award-winning ${ }^{29}$ museum was selected as focus of our study for its complexity and multifaceted nature. In 2006 the proposal of the temporary association Stéphane Beel Architects / Origin / Kortekaas / Desvigne / Arup / BB / RCR / Daidalos won the competition launched by the Federal Building Agency to modernise a highly protected heritage building, and respectfully express its history. ${ }^{30}$ Dated 1910 , the museum was in need of restoration, renovation, and expansion ${ }^{31}$ (Figure 1) to meet contemporary requirements and express its current values, including (wheelchair)-accessibility. ${ }^{32}$ Completed in 2018, the museum consists nowadays of two main volumes - original and expansion - connected underground, with distinct functions and character (Figure 2).

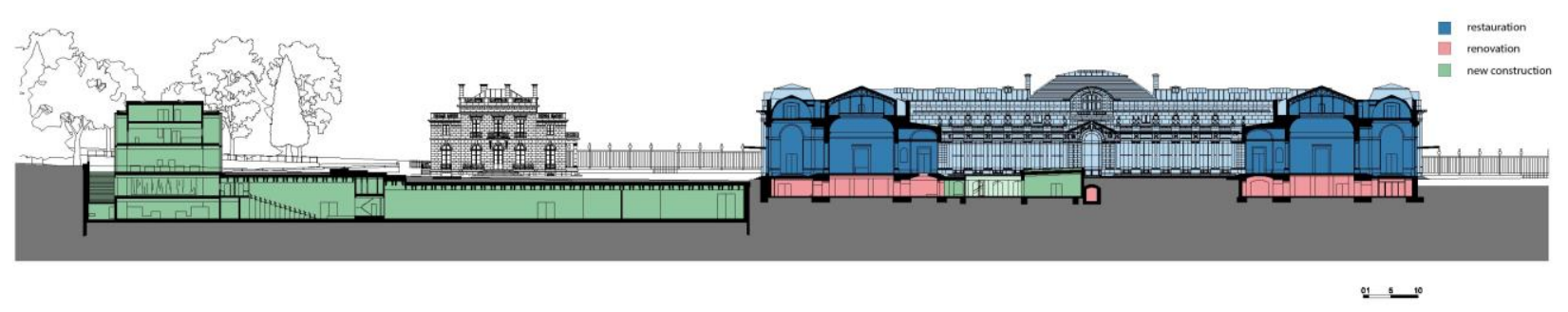

Figure 1. Longitudinal section of the KMMA. New construction areas are marked in green; areas that have been renovated are marked in pink; and areas that have been restored are marked in blue. (C) Stéphane Beel Architects 


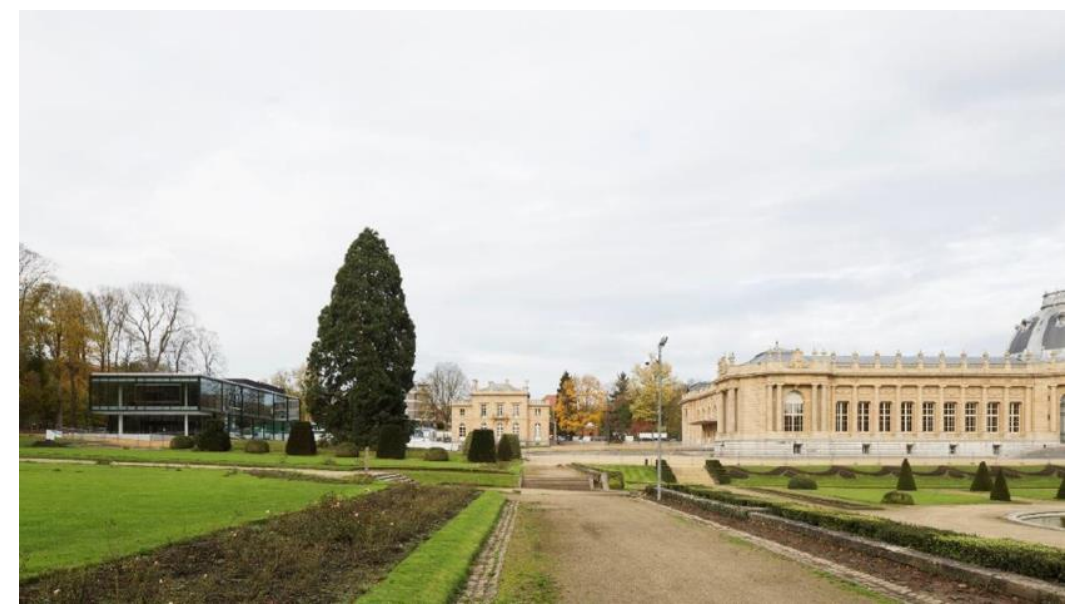

Figure 2. The new building is located on the left, and the old building dated from 1910 is located on the right; both are connected underground. (C) Luca Beel

To gain insight into how particular material features of the KMMA relate to Stéphane's anticipation of using a wheelchair, we use some techniques of focused ethnography. While preserving the essential nature of conventional ethnographies, i.e. revealing what particular cultural groups do, know, believe in, or value, focused ethnographers pursue pre-selected research questions; enquire about specific attributes of smaller cultural groups that the researcher(s) partially share; use intensive data collection strategies; and acknowledge how characteristics of the researcher(s) shape the research at hand. ${ }^{33}$

In focused ethnographies an extensive use of audio- and video-recording devices and a more thorough preparation beforehand compensate for short field visits. ${ }^{34}$ In our study, we employed three data collection strategies: gathering and studying published material and relevant design documents; interviewing Stéphane Beel and renovation architect Robin Engels from Origin; and observing and interacting with Stéphane during two by him guided tours in two of his buildings, the KMMA and the Raveelmuseum. ${ }^{35}$ The KMMA, the focus of our study, was visited by the first and second author with Stéphane four months before officially being opened 
to the public. During the guided tours, observation and interviewing occurred simultaneously. Having Stéphane guide the interviewers through the buildings helped stir up memories of design decisions or processes leading to their materialization, and facilitated observation and expression of experiences as they unfolded in (one of) their natural settings. Central to most forms of qualitative enquiry is the idea that human actions - situated by nature - can be properly understood only in context. ${ }^{36}$

After the KMMA was opened to the public, all authors re-visited it - without Stéphane. Re-visiting offered an opportunity to experience the museum during a regular day and gain further insight into how it performed. All field visits have been crucial to study how his anticipation of using a wheelchair has affected the design of the KMMA and enquire about what is said, what has been done, and the relation between both.

During the audio- and video-recorded interviews with Stéphane the interviewers asked him, amongst others, what he understood by certain concepts such as 'disability' and 'independence' to make sure they had a similar understanding. During the second guided tour at the Raveelmuseum, several months after the first one, follow-up questions invited to clarify, or further reflect on, relevant comments and observations. After all interviews had been transcribed verbatim, data analysis was performed roughly following QUAGOL. ${ }^{37}$ Its analytic strategy proposes, amongst others, an iterative reading of all collected materials. After going through the interviews several times, all three of us made, shared, and discussed content reports and concept lists. We drew a unified concept list, from which codes and themes were developed and verified with the empirical material. Qualitative software served as a data management tool for organizing segments of similar or related materials, which assisted their interpretation. How interview quotes, concepts, codes, and themes relate can be consulted in Table 1. Coded 
fragments were analysed in response to the research question. Five main themes were identified in relation to how Stéphane's anticipation of using a wheelchair plays out in his life: encountering incomprehension, acquiring empathy, building with empathy, unlocking empathy, and gaining insight.

Few researchers (e.g. in anthropology, sociology, or architecture) studying intersections between architectural design and disability are disabled themselves. ${ }^{38}$ While it can be argued that every researcher contributes to knowledge from their own lens and expertise, the first author, Natalia, brings a unique perspective - that of an architect, experienced wheelchair-user, temporary user of the building under study, and researcher. To our knowledge, the convergence of these lenses, and how they relate to Stéphane's imagined situation, cannot be found in other studies on architecture, disability, or empathy. In making use of this lens, we expect to obtain deep and authentic insights into the role of empathy in design (practice), and the role of the embodied self therein. Especially in anthropology, scholars recognize advantages in disabled researchers conducting research on disability-related topics and for them to use their perspectives and first-hand knowledge as a strength. ${ }^{39}$

Particularly in focused ethnography, a partial overlap between researchers' and participants' features is considered an advantage to compensate for a shorter time in the field. ${ }^{40}$ It allows the researcher to better understand complexities surrounding issues from the participants' perspective, while bringing the outsider's framework to the study. ${ }^{41}$ In our case, this overlap foregrounded, and further encouraged, mutual interest, observation, and interaction. Consistent debriefing and discussion among all authors promoted critical reflexivity and helped keep potential biases in check, while preserving the richness of the data. ${ }^{42}$ 


\begin{tabular}{|c|c|c|c|}
\hline Quotes / Unit of meaning & Concepts & Codes & Themes \\
\hline $\begin{array}{l}\text { I couldn't eat, I couldn't coordinate my } \\
\text { fingers.... this I couldn't do that, that's so } \\
\text { obvious to do that, and when you don't, } \\
\text { then you realise it's quite complicated to } \\
\text { do all this coordination, between your } \\
\text { eyes, between your fingers, between } \\
\text { everything. }\end{array}$ & $\begin{array}{l}\text { Fluctuation } \\
\text { Mobility / Balance } \\
\text { Senses }\end{array}$ & Physiological Impact & \multirow[t]{5}{*}{ Impact of Impairment } \\
\hline $\begin{array}{l}\text { I try to control things, but at the same } \\
\text { time I know that that is very absurd. For } \\
\text { example, my people and I are doing a } \\
\text { huge amount of work to put buildings as } \\
\text { we have in mind, but things can always } \\
\text { happen that you cannot control, no } \\
\text { matter how hard you try. }\end{array}$ & $\begin{array}{l}\text { Acceptance } \\
\text { (Lack of) Control } \\
\text { Uncertainty }\end{array}$ & Psychological Impact & \\
\hline $\begin{array}{l}\text { There is an opening, or we have a drink, I } \\
\text { have to lean on someone, or I have to sit, } \\
\text { and then sitting-and then you have a } \\
\text { different way of talking to the people. And } \\
\text { we are treated in a different way, and I } \\
\text { don't like it, that I don't like it. }\end{array}$ & $\begin{array}{l}\text { (Lack of) Understanding / } \\
\text { Sensitivity } \\
\text { Expectations / Social Conventions } \\
\text { Visible vs. Invisible }\end{array}$ & $\begin{array}{l}\text { Impact of/on the Social } \\
\text { Environment }\end{array}$ & \\
\hline $\begin{array}{l}\text { Independence is - I'm depending from a } \\
\text { chair, for example, not trom a person but } \\
\text { from some thing that would help me to } \\
\text { get- I can't stand for three minutes, I } \\
\text { would fall, so, I'm more dependent. }\end{array}$ & $\begin{array}{l}\text { Sitting / Leaning } \\
\text { Space / Spacious }\end{array}$ & $\begin{array}{l}\text { Impact of/on the Built } \\
\text { Environment }\end{array}$ & \\
\hline $\begin{array}{l}\text { I don't teel disabled, I don't have a } \\
\text { sticker on my car. So, I don't park my car } \\
\text { anywhere. }\end{array}$ & $\begin{array}{l}\text { Ambivalence / Ambiguity } \\
\text { Definition of Disability } \\
\text { Gift / Luck }\end{array}$ & Identity / Self-Image & \\
\hline $\begin{array}{l}\text { You can't do all the things, but you can } \\
\text { be aware of that, and that's- this is quite } \\
\text { important that you can take into account. }\end{array}$ & $\begin{array}{l}\text { Future Possibility } \\
\text { Understanding / Sensitivity } \\
\text { Limitations (imagination vs. } \\
\text { Knowledge) }\end{array}$ & Imagination & \multirow[t]{3}{*}{ Acquiring Empathy } \\
\hline $\begin{array}{l}\text { If I would stand, then I have to } \\
\text { concentrate on my [balance] and then it's } \\
\text { a little bit more difficult to get a nice } \\
\text { conversation in a way that you have to be } \\
\text { able to think and to focus. }\end{array}$ & $\begin{array}{l}\text { Embodiment } \\
\text { Wheelchair-User }\end{array}$ & Resonance & \\
\hline $\begin{array}{l}\text { As an architect you have to be in } \\
\text { someone- in poople's head anyway, you } \\
\text { have to understand them, you have to- } \\
\text { ah, they say } \\
\text { something, but you have to understand } \\
\text { other things than what they say, so, the } \\
\text { nice thing is that, most of the time, I have } \\
\text { dinner with them. }\end{array}$ & $\begin{array}{l}\text { Interaction } \\
\text { Observation } \\
\text { Spending Time With People / } \\
\text { Having a Relationship / Connection }\end{array}$ & Working with/for People & \\
\hline $\begin{array}{l}\text { You have to be in another potions, you } \\
\text { have to be another person, and if you are } \\
\text { looking at it with some strange eyes, you } \\
\text { will- you can see if it's real worthy. }\end{array}$ & $\begin{array}{l}\text { Alienation / Sense of Strangeness } \\
\text { Care } \\
\text { Consultancy } \\
\text { Multiple Perspectives } \\
\text { Repetition } \\
\text { Testing }\end{array}$ & Thinking of Others in Design & \multirow[t]{5}{*}{ Building with Empathy } \\
\hline $\begin{array}{l}\text { I want to visit my own buildings until I die, } \\
\text { yeah, like that, within a month I can be in } \\
\text { a wheelchair, a lot of people that have my } \\
\text { disease are. }\end{array}$ & $\begin{array}{l}\text { Embodied Knowledge } \\
\text { Imagining his Future Self }\end{array}$ & Thinking of Self in Design & \\
\hline $\begin{array}{l}\text { You look around, where you will find the } \\
\text { elevator, it's obvious that you will find the } \\
\text { elevator in the black box, it' even- it } \\
\text { stands on little signs, but it's obvious. }\end{array}$ & $\begin{array}{l}\text { Accessibility } \\
\text { Added Value / Do more } \\
\text { Aesthetics } \\
\text { Context } \\
\text { Equality } \\
\text { Heritage } \\
\text { Independence / Choice } \\
\text { Legislation / Codes } \\
\text { Light } \\
\text { Primary vs. Secondary Route } \\
\text { Special Design / Exception } \\
\text { Visible vs. Invisible } \\
\text { Wayfinding / Legibility }\end{array}$ & KMMA Features & \\
\hline $\begin{array}{l}\text { Right from the start when we made the } \\
\text { first drawings, we were sitting around the } \\
\text { table with } 12 \text { people, specialists in } \\
\text { museum design, specialists about Africa. }\end{array}$ & $\begin{array}{l}\text { Client } \\
\text { Competition } \\
\text { Context }\end{array}$ & $\begin{array}{l}\text { KMMA Implementation / } \\
\text { Design Process }\end{array}$ & \\
\hline $\begin{array}{l}\text { SB: People have for example } \\
\text { agoraphobie, you know what the- the } \\
\text { term? NPL: Unh-huh, fear of too open } \\
\text { spaces. SB: fear of- too open, at the } \\
\text { same time, you have claustrophobie, for } \\
\text { me it's not in the right proportion of } \\
\text { bulding. }\end{array}$ & $\begin{array}{l}\text { Abstraction } \\
\text { Connection / Belonging } \\
\text { Organization of Space } \\
\text { Proportion } \\
\text { Space / Spacious }\end{array}$ & Features of Other Designs & \\
\hline $\begin{array}{l}\text { It doest't mean that you have to be } \\
\text { negative, but you have to replace yourself } \\
\text { in the position of someone else, and } \\
\text { without saying that you completely can } \\
\text { be in the place of someone else, but you } \\
\text { can feel some things, yes. }\end{array}$ & $\begin{array}{l}\text { Authority } \\
\text { Common-sense / Internalization } \\
\text { Getting Personal / Self-Reference } \\
\text { Using Emotions / Affect }\end{array}$ & Using Himself as Argument & Unlocking Empathy \\
\hline $\begin{array}{l}\text { You have a quite a long plattorm, and } \\
\text { then you have another step, and this step } \\
\text { people don't expect and so people- } \\
\text { already people have fallen from it, even, } \\
\text { you see the difference in colour, people } \\
\text { are talking to each other and they don't } \\
\text { pay abtention to it, and we already made } \\
\text { an abstract element into it. }\end{array}$ & $\begin{array}{l}\text { (Lack of) Control } \\
\text { Retrofitting } \\
\text { Unpredictability }\end{array}$ & Acceptance & \multirow[t]{3}{*}{ Gaining Insight } \\
\hline $\begin{array}{l}\text { I think every architect ought to be a stage } \\
\text { director. You are the director of particular } \\
\text { lives and there should not be too much } \\
\text { arrogance and pretension on your part, } \\
\text { but you have to have to be aware that } \\
\text { you are directing the lives of particular } \\
\text { people . That you are making certain } \\
\text { things impossible or actually possible. }\end{array}$ & $\begin{array}{l}\text { Function / Purpose / Impact of } \\
\text { Design } \\
\text { Effect on (Disabled) People }\end{array}$ & Responsibility & \\
\hline $\begin{array}{l}\text { For me it's also interesting to be } \\
\text { confronted with these questions. }\end{array}$ & $\begin{array}{l}\text { Confrontation } \\
\text { Discovery } \\
\text { Interaction }\end{array}$ & New Opportunities & \\
\hline
\end{tabular}

Table 1. Examples of quotes, concepts, codes, and themes. 
Stéphane and Robin were fully informed prior to participation; they gave written and verbal consent for interviewing and recording after reading an Informed Consent Form describing our study and its confidentiality provisions, approved by the Social and Societal Ethics Committee of KU Leuven. Stéphane and Robin did not request to remain anonymous neither throughout the study nor in any publications.

\section{Findings}

\section{Encountering Incomprehension}

Stéphane describes various social implications resulting from the physical effects of his disease.

Even while being in remission, he expresses not being symptom-free. Residual symptoms

include problems with balance and coordination; difficulties in standing still for prolonged

periods of time; uncontrolled movement; fatigue; and lingering sensory issues (e.g. odd sensation

in his hands, or hearing and vision problems). That these symptoms are not readily discernible

makes it difficult for people who are unaware of his disease to understand his actions and

behaviour. The image he projects to others, he points out, is not one of a (typical) disabled

person, but one of a person who is publicly exhibiting unconventional behaviour. This

incomprehension towards him is palpable in the following excerpt:

One week ago I gave a lecture ... and I had to stand. I was not at ease and this was quite difficult. ... Afterwards [a family member among the audience] told me that people thought I had 'a good dinner'. And that angers me. [My family member] said 'maybe you have to say it before [the lecture] so that people don't think that'... People easily think ' $a$, he's drunk'. And I thought all people [in] Belgium know I have this disease because I've spoken it out on the radio, even on television, even in books, and interviews. ... A lot of people can't see I 
have this. For you it's obvious, so they can take it into account. ... [For me] it's not obvious and people think other things (interview 2019).

Stéphane compares the incomprehension he encounters with Natalia self-evident situation of being a wheelchair-user. He believes it is unnecessary for her to be explicit about her actions, as a basic understanding of her capabilities and behaviour can be read off of her projected image. Stéphane dislikes the need to be explicit about (the effects of) his disease and, in that sense, expects it would be more convenient if it were more visible (e.g. by the use of a wheelchair). However, he also recognises that a visible impairment could be a burden, as it may be present in moments it does not need to and/or dominate one's personhood.

\section{Acquiring Empathy}

Stéphane expresses not fully identifying with 'being disabled', although he confesses feeling disabled in certain situations (e.g. the one described above). Even though never having had a seat in a wheelchair, since his diagnosis he has been living with the possibility of using a wheelchair sometime in the imaginary future. Regardless, his progressive-regressive disease has produced similar situations as (i.e. resonances with) those some wheelchair-users experience. Striking parallels between these two seemingly diverging bodily realities include preferring to sit during presentations or receptions (and even 'depending on a chair' (interview 2019)); struggling to connect with people in social gatherings; preferring to take an elevator when stairs go down; experiencing difficulties in moving while holding something in his hands; occasionally losing body control and/or moving involuntarily; or needing to plan certain activities ahead to achieve comfort. 
These parallels, combined with bodily uncertainty and his anticipation of using a wheelchair, seem to nurture an outspoken sensitivity towards disabled people - particularly wheelchair-users. In both interviews and several articles, ${ }^{43}$ Stéphane consistently identifies also positive sides of his disease, e.g. heightening his sensitivity. He explains how his disease has affected his design practice:

it's not only the way I perceive buildings, it's the way you're working with people, you're treating people, you have a relationships with people. ...As an architect you have to be in people's head anyway. You have to understand them. You have to understand other things than what they say (interview 2018).

$\cdots$

Maybe if I was a healthy man ... I would have been less sensitive, and also more rude, pretentious ... Being pretentious means that you don't care about other people, about other situations. That you care most about you; about your situation. ...Y You have to realise that people can be different ... and you have to take it into account. That's the main thing that changed me. And I'm happy with that (interview 2019).

To achieve this understanding, and to strike a balance between forcing his own views and desires and considering his clients', he stresses the importance of spending time with them. For instance, sharing meals with clients not only boosts conversation, but also allows him to observe them beyond the explicit.

Stéphane further points out that, although during design he sometimes finds it inevitable to think of himself, he recurrently imagines being someone else, and goes over a design numerous of times from various angles. Stéphane mentions to have always had the ability to place himself in other people's situations in general (not just regarding disabled people's). However, this ability intensified, he highlights, as his condition progressed. Within this 
imagination exercise, introducing a sense of strangeness seems to be important:

[During the design process] you have to place yourself in the situation of a wheelchair-user, of a cook, or someone who cleans. ...Y You have to place yourself in the position of other people. ...You have to be another person. And if you are looking at [the design] from some strange eyes, you see if it's worthy (interview 2019).

Whereas Stéphane explains requiring consultants for specific design tasks, he himself enacts, and thereby tests, in his office certain situations, e.g. simulating a wheelchair-user's eye height. Nevertheless, he acknowledges essential differences between being in and imagining someone else's circumstances. While one can imagine being in someone else's situation and reach an understanding of their feelings, thoughts, and needs, one can never have full knowledge: 'you have to place yourself in the position of someone else, without saying that you can completely be in the place of someone else. But you can feel some things. ...You can't say "I know what you're feeling". You can't. It's not the same' (interview 2018).

\section{Building with Empathy}

Considering Stéphane's disease has affected how he regards himself and others during the design process, we further examine how his outspoken sensitivity finds its way into materialised design. To this end, we focus on specific aspects - social, functional, and aesthetic - of the KMMA's (wheelchair-)accessibility.

For Stéphane, architects need to do more than what is explicitly asked of them and find various possibilities around one design problem: 'if you have one reason to do something, then it's no good. ...If you don't add possibilities, if one solution for one construction detail is not, at 
the same time, something else, throw it away' (interview 2018). He applies the same approach for accessibility: 'if it's not connected to other things, then [it's not good]. Because then you make accessibility a special thing and [then] it's only for [disabled] people' (interview 2018). Solving functional aspects of accessibility - giving access - is the minimum, he believes, and other things like e.g. relationships between spaces, wayfinding, aesthetics, or sensory comfort need to be balanced against purely formal aspects (e.g. proportion, line, or composition). Hence, going beyond what regulations prescribe seems to be important to him; accessible elements should not stand on their own, but be designed to provide significant added value to the overall design, and (therefore) be used by a broader population.

Stéphane prefers to provide a variety of people with the same entrance, route, and use in his buildings (i.e. offer the same experience). In the KMMA's former layout, the main entrance and the entrance for wheelchair-users had been separate: '[wheelchair-users] had to ask for special things. You can't do that. They have to enter [through] the same entrance as all the people' (interview 2018). The extension added to the KMMA offers a new entrance to the museum, where every visitor enters the same door. Nonetheless, whenever segregation is inevitable (e.g. elevator-stairs), the design team tried to ensure that the length of both routes is as similar as possible (i.e. offer equal experiences). Attention was thus given to how elevator and stair routes relate to each other, rather than treating both as separate problems to be solved within the same building. Reflecting on the joint visit, Stéphane points out: 'what I showed you at the KMMA [is that] I went up the stairs and you took the elevator [and] we saw [each other] quite at the same moment and we were at the same place. ...I [do] my best to have almost the same length of time and meters for a wheelchair-user' (interview 2019). Similarly, the design team converted a set of strategically positioned steps into soft ramps to be used by every visitor, 
avoiding giving the impression that they are specially meant for wheelchair-users (Figure 3).
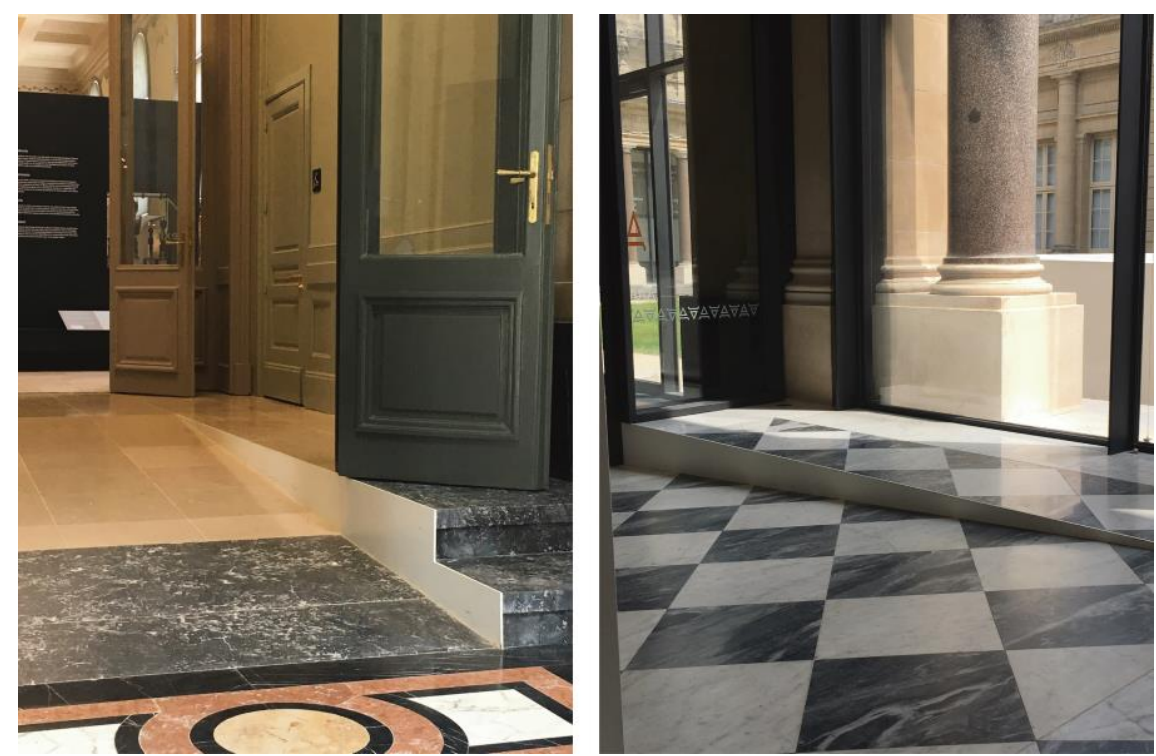

Figure 3. Two examples on how former steps have been converted into ramps in the old building. (C) Natalia Pérez Liebergesell

For Stéphane, 'equality' and 'independence' seem to be important, and closely linked, concepts. He associates independence in design with the availability of choices and freedom of movement; KMMA visitors should be able to get around on their own, without needing to ask, or depending on, other people. At the same time, visitors should have the choice to deviate from the main route if wished for, without getting lost. Hence, wayfinding needs to be suggested by architecture itself, rather than excessively pronounced by signage or other overly-steering elements (Figure 4). For instance, at the KMMA the design team chose 'light' as a natural indicator to provide visitors with directionality, while still offering opportunities to meander. The exhibition starts at the -2 underground level, from where visitors gradually ascend towards the luminous areas of the ground level. During the guided tour, Stéphane seems to enjoy putting the KMMA to test by letting Natalia find her way without leading her. ${ }^{44}$ Re-encountering at one of the elevator-stair intersections, he points out: 'you looked around and then you saw [where you 
needed to go]. I didn't say anything' (interview 2018).
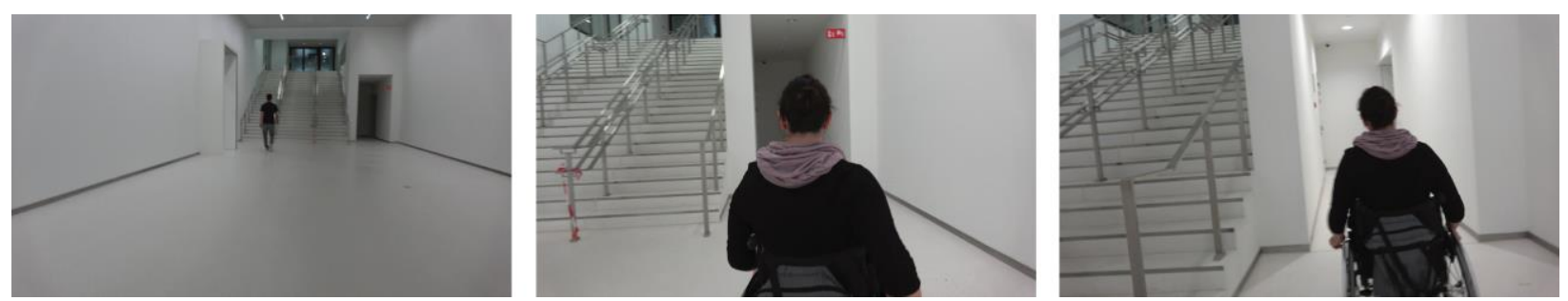

Figure 4. Sequence of three photographs illustrating how Natalia is looking for the elevator. The passage next to the stairs suggests where to go. (C) Peter-Willem Vermeersch

Whereas Stéphane seems to be mindful of dynamic aspects of (wheelchair-)accessibility regarding movement and use, he also seems to be concerned with static features related to appearance. At the KMMA's restored and renovated section, for instance, the design team was especially attentive to aesthetic/visual features of four platform lifts (two square ones standing alone (Figure 5), and two round ones encased between walls (Figure 6)), and how they relate to their heritage context. During the visit Stéphane invites Natalia to use them. While she gets prepared to descend in one of the square platforms, he remains quiet, seemingly awaiting for her to react on its appearance:

Natalia: It's nice. It doesn't look so heavy as you sometimes see.

Stéphane: It's not ugly! It's [bad enough] to be disabled, to have to get into this ugly thing. (interview 2018)

Unlike the often ugly-looking add-on platforms, the square platform lifts seem to elegantly connect with the (historical) elements around them: their perimeter is almost transparent, the marble floor patterns match the ones around them, and the transition between platforms and floor is smooth and practically imperceptible. 

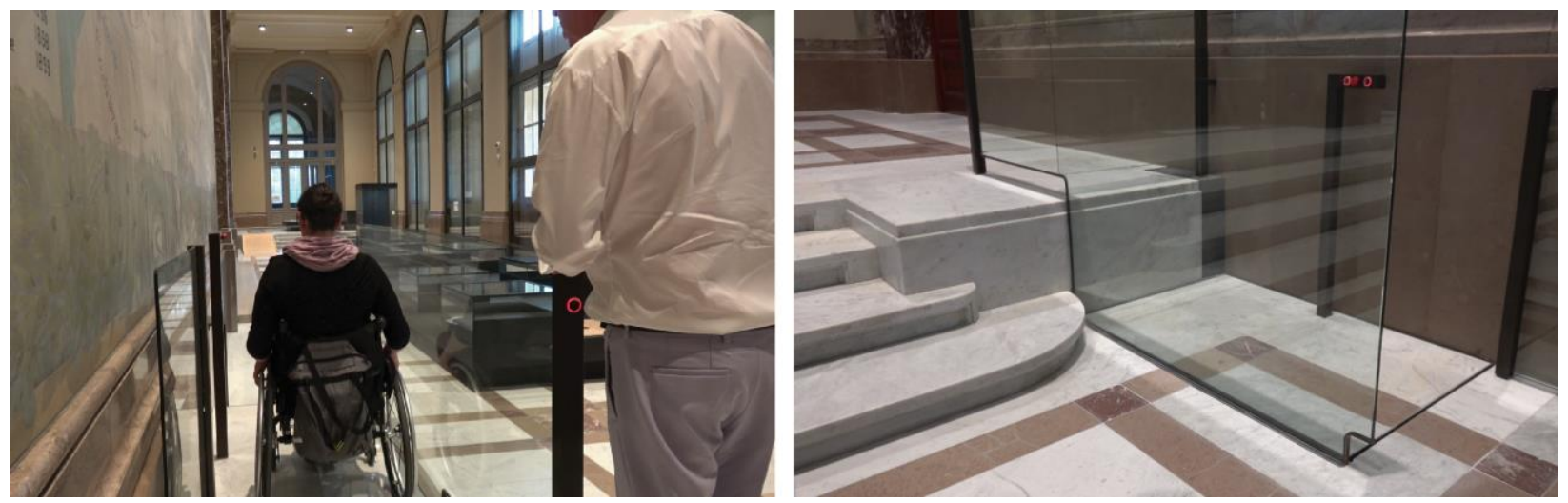

Figure 5. Stéphane observing how Natalia uses the square platform lift. @ Peter-Willem Vermeersch
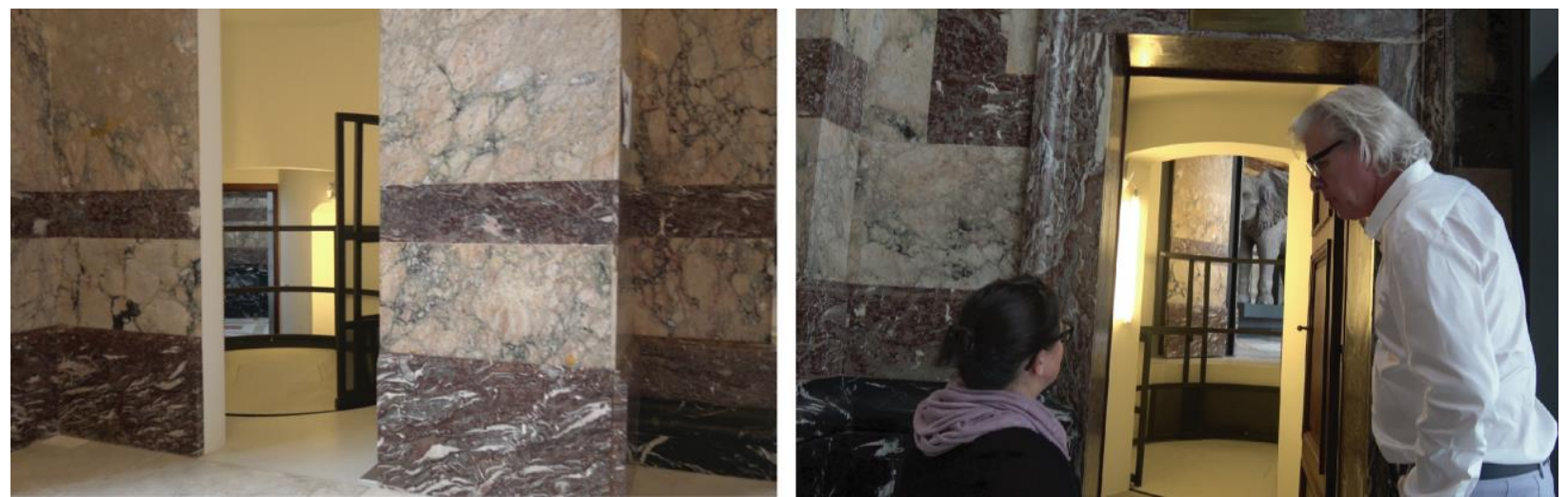

Figure 6. Stéphane and Natalia commenting on the round platform lift. ( $)$ Peter-Willem Vermeersch

The rounded platform lifts have a different character. Encased between walls they are less visible; the materials used look light and modern and thereby more contrasting with their context. While the square platforms are small and afford one wheelchair-user at a time, the round platforms quadruplicate in size, affording a larger number of people. Additionally, the round platforms are facing one another, and are located at both sides of a big 'rotonde', the space between the two wings of the symmetrical building (Figure 7). Contrarily, both square platform lifts have been installed at opposite wings of the building, without immediate relation with each other. For the area they give access to they are the only entry/exit option for wheelchair-users. After visiting this area, these visitors are thus required to retrace their route: 
Stéphane: You only have one [platform], so you have to come back. We didn't want [another platform] on the other side.

Natalia: You didn't want? Or because of budget?

Stéphane: No, I can't blame it on the budget.

Natalia: Why didn't you want another [platform]?

Stéphane: Because it was too much. I think you don’t have to go that far. It takes you half a minute and then you'll be out again. It's a decision: it's too far or not.

(interview 2018)
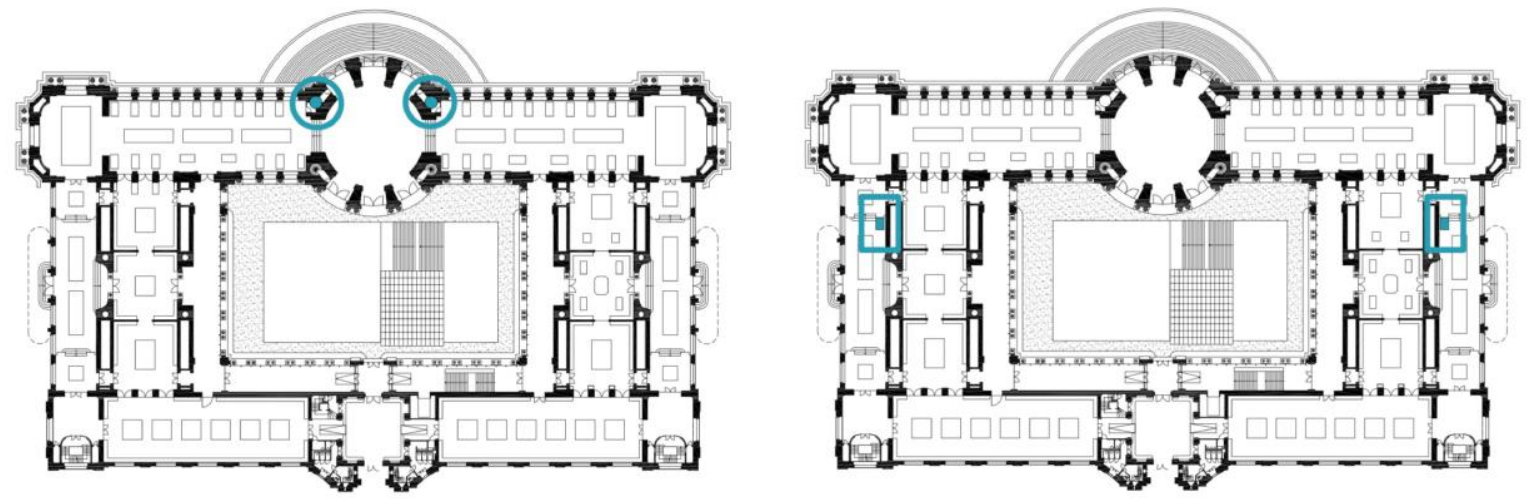

Figure 7. Two floor plans of the old building highlighting the two round platform lifts (marked in the left floor plan) and the two square ones (marked in the right floor plan). () Stéphane Beel Architects

Asked whether the KMMA design had taken other impairments into account, he briefly mentions vision and hearing impairment, connecting them to a partial overlap with sensory issues derived from his disease. While Stéphane admits acoustics not having been 'well treated' in the refurbished section of the museum, the design team dealt with reverberation in the extension. 
'It's not only for disabled people, it's for people in general. [It's important] that you feel at ease' (interview 2018). Similarly, Stéphane connects his own vision problems with how light, contrast, and glare was dealt with at the KMMA, and beyond, how a wider range of people could benefit from taking these features into account. How the design team sought various possibilities around one design problem can be extracted from the following interview excerpt:

I'm aware that you have to have contrast; dark and light has to be clear. Or, for example, for people who don't see very well, it's good to have another material [on the floor], and that you can feel it with [your feet]. Or, for example, here, in the upper [level] the floor is the most dark, because you have the most light. If you are going down [one level], you will see that [the floor] becomes [lighter], and in the [lowest level] it's white. By this you understand where you are, you see these differences (interview 2018).

\section{Unlocking Empathy}

Asked how he convinces resistant stakeholder(s) to implement accessible elements, Stéphane distinguishes three different stages he goes through, depending on the resistance encountered: (a) convincing people in a 'normal' way by talking to them; (b) inviting them to momentarily put themselves in the shoes of an impaired person; or (c) confronting them with his own anticipated future situation. Pointing at the former steps that were converted into a ramp, he explains:

Stéphane: What you see [here], it was not that easy. These were two steps. We made this a slope.

Natalia: And how did you manage to get it through?

Stéphane: Yeah, but okay, it's common sense. 
Natalia: But was it also common sense for the heritage people?

Stéphane: Not for [them]. We'll see some other things we had to fight for.

Natalia: And how would you fight for it?

Stéphane: You can convince people in a normal way, and what normal people can discuss. And if that doesn't work, I use some other things. For example, the same way you were involved in an accident, or can have a disease- 'maybe within two weeks you are paralyzed. You don't want to visit [the museum] anymore? No? And how will you do it?'

Natalia: That's what you would say?

Stéphane: Yeah, absolutely. Then I get very angry. Very personal. ... I would say: 'within two weeks you're disabled. Think about it. ... Do you think you're above nature? Do you think that some diseases or something cannot happen to you? ... Is it so difficult to imagine that you are in a wheelchair? You never had anything?'

(interview 2018)

Whenever general discussion (a) does not work, Stéphane tries fostering people's empathy by taking the conversation to the personal arena (b). With a very straightforward demeanour, he confronts the resistant stakeholder(s) by means of imaginative processes and by stimulating affect with the hope to bring them closer to the topic. Besides seeking an affective response of the other(s), he seems to make his own affective and emotional state explicit to them (e.g. by getting very angry).

As an additional argument to counter opposition, Stéphane mentions to recurrently confront people with his bodily uncertainty (c). Explaining his own situation to opposer(s) seems to help trigger further understanding: 'I do it in reverse. I say: "I want to be able ... to go to my 
own building and to have the possibility to visit it still." ... I want to visit my own buildings until I die. Within a month I can be in a wheelchair. A lot of people that have my disease are.... If you get personal you can understand [better] what the problem is.' (Interview 2018).

\section{Gaining Insight}

Stéphane seems to be aware of, and even accepting, the many things about his buildings and their contexts that are out of his control. Buildings are part of an ever-changing societal, material, and climatic context necessary to have knowledge about, but impossible to dominate: 'I try to control things, but at the same time I know that is very absurd ... [T]hings can always happen that you cannot control, no matter how hard you try. I do not see that as a limitation, but as something positive' (SB in De Standaard, 2011). Buildings are used, and are therefore prone to (sometimes unpredictable) change. Similarly, Stéphane seems to accept that both, knowledge and empathy, have certain limits; architects cannot design for everybody, in every situation, all the time, for all future scenarios. Architects, however, need to be aware of their roles as enablers and disablers:

[Architects] are the directors of particular lives and there should not be too much arrogance and pretension on your part, but you do have to be aware that you are directing the lives of particular people. That you are making certain things impossible or actually possible.

(SB in Marquez and Lavene, 2006)

Striking throughout the guided tours is Stéphane's honesty: he does not hide away what had not been solved well, but rather points at errors and oversights himself. Natalia's presence further stirs up questions whether something is 'right' or 'comfortable' for her. Recurrently Stéphane crouches down beside her to get himself to a similar eye sight as hers, while asking questions 
like 'is it comfortable for you?'; 'can you see through it?'; 'is it accessible?'; 'you find it dangerous?' (interview 2018, 2019).

Overall, Stéphane refers to this study's topic and interview questions as a positive confrontation. They have made him consider further ways of intersecting disability and architecture: 'maybe I have to be aware that we have to do more out of this. Yeah, it's good, it's nice. ... I think it's good for me to talk about it, even to show it [to you], and that you react on that.' (interview 2018). As a result, Stéphane sees new opportunities arising in (his) architecture. During the first interview he began to play with the idea of discovering alternative ways of approaching accessibility, moving from 'equal' or 'same' experience, to making accessibility an 'aesthetic' experience, e.g. making an attraction out of it, an adventure, a competition, or encouraging new ways of looking.

\section{Discussion and Conclusions}

\section{The Other}

Within the phenomenological tradition, bodily presence is argued to be crucial in empathic processes. ${ }^{45}$ However, our findings suggest that Stéphane's bodily presence is not sufficient to provide a particularly profound understanding of his situation; he encounters a lack of empathy from others despite his presence. In these situations, what seemed to be missing were narrative and contextual factors for others to enact imaginatively, e.g. knowing that Stéphane has MS and understanding what it entails. In relation to disability, Butler and Bowlby ${ }^{46}$ corroborate Stéphane's view insofar that, in some circumstances, evidence of 'visible' impairment can prevent hostile or hurtful reactions. Empathising requires an enactable, contextual narrative that 
transcends mere bodily presence: ${ }^{47}$ the self is compelled to find reasons that allow making sense of situations by situating the other in a meaningful context. ${ }^{48}$

The notion of immediacy in empathy may also be contrasted with the concept of affect and its unfolding throughout time. Our findings align with a less literal understanding of bodily presence in empathy. ${ }^{49}$ They suggest that past encounters with others may affect one's orientation towards others in the present, i.e. one's willingness to empathise. What catches one's attention and triggers empathy may not be prompted 'naturally' at a particular moment in time and in the presence of others, but is intertwined with previous experiences and/or bodily changes, and learned and cultivated across one's lifespan. ${ }^{50}$ The affective body 'preserves the traces of past actions and encounters and brings them into the present as potentials' ${ }^{51}$ These 'traces' determine a person's orientation; when to try and make the other comprehensible to the self, or when to look the other way. An encounter in the past may thus be relevant sometime in the future, e.g. informing or 'affecting' future designs. Similarly, anticipating a specific future scenario and its effect on the present, as Stéphane does, significantly shapes his orientation towards attending to (wheelchair-)accessibility; triggering a powerful response in the 'here and now'.

\section{The Other as Self}

Affect is also part of what empathising is. Besides having access to narratives, one must feel an affective connection to the other; narratives need to be appropriated and enacted as if they were one's own. Stéphane clearly states not identifying with being disabled, yet, 'the disabled' are not cleanly categorised as 'no-me'; rather the contrary. He embeds (wheelchair-)accessibility in his designs from the outset, has incorporated its importance, and clearly sees a point in going beyond 
what regulations prescribe. For many, impairment is something that happens to the 'other'. ${ }^{52}$ While everyone can potentially become impaired ${ }^{53}$ the lack of concreteness of 'impairment' may be a significant hurdle in putting empathy in motion, and incorporating an abstract and (felt as) unlikely situation as one's own. In contrast, whereas the effects of MS may be varied, they are also concrete (e.g. potentially using a wheelchair). Stéphane can - and is willing to - enact certain narratives related to impairment. In Marshall and Hooker's ${ }^{54}$ vocabulary, his incorporation of the other as self is productive; it produces concrete effects in his architecture and it shifts interactions with those he encounters during the design process.

\section{The Self}

Like Heylighen and Dong ${ }^{55}$, Bos and $\mathrm{Kal}^{56}$ point out that 'the recognition of difference, dissimilarity, leads to the recognition that not everything can be bridged, but certainly a part is bridgeable, connectable'. One may be better equipped to empathise with parts of the other one recognises as similar to the self, yet, what constitutes similarities and differences?

Acknowledging potential overlaps between having an impairment and being temporarily disabled in particular circumstances may be relevant to reduce the perceived gap between self and the distant, disabled other. ${ }^{57}$ Without identifying himself as disabled, Stéphane articulates several disabling situations that he has found himself in and, in turn, allow him to connect with wheelchair-user narratives. Thus, an architecture student needing to open a door while carrying a voluminous scale model, or a parent carrying a baby in that same 'disabling' situation, could uncover potential resonances with impairments related to the unavailability of hands or - with regard to wheelchair-use - having difficulties opening certain doors. Unearthing and relating these resonances across embodied selves and others may be a promising route to put empathy in 
motion in design processes.

Resonances may further relate to Stéphane's wish to find more than one reason for designing an architectural element, i.e. identify which elements are considered necessary for certain end-users, and how those enhance comfort for others within the overall architectural concept. On the one hand, he seems to understand that designing for people with an impairment can and should be more than providing ramps, elevators, or platforms as a separate endeavour. The design team attends to contextual and social aspects in design related to equality, context, wayfinding, independence, or aesthetics - whose lack is said to contribute to 'disabling' a person besides their impairment. ${ }^{58}$ These attributes, in turn, resonate with facilitating and/or enhancing the experience of the building's users - impaired or not.

On the other hand, Stéphane does not always seem to apply his own design principle of 'doing something for more than one reason'. Whereas it cannot be denied that the design team put effort in the platform lifts' appearance, independent use, and integration into their context, many wheelchair-users (e.g. architect Marta Bordas Eddy ${ }^{59}$ ) would refer to platform lifts as 'special designs' deliberately designed for 'the disabled'. For her, a platform exemplifies the suppression of architectural barriers, but not good design. It is unlikely to be used by nonimpaired people due to its disability-stigma, even though it may provide assistance to e.g. people at older age, carrying heavy items, or pushing a pram. It can be hypothesised that the size and shape of the round platforms (which are bigger and reminiscent of elevators) may outperform the attached stigma and entice more people to use them besides wheelchair-users.

\section{The Self as Other}


As mentioned, many architects tend to design from their own perspective. ${ }^{60}$ Stéphane occasionally tries doing the opposite: introducing a sense of strangeness during the design process by taking up diverse roles to test how the design responds to various end-users. This selfdissolution (Selbstauflösung) or distance to self may facilitate other-inclusion, i.e. assimilating others' perspectives. ${ }^{61}$ Davis $^{62}$ stresses that understanding as a result of imaginative perspective taking may be considered a substantive aspect of the larger phenomenon of empathy. Furthermore, Dymond ${ }^{63}$ directly relates empathy to imagination: empathy is 'the imaginative transposing of oneself into the thinking, feeling, and acting of another and so structuring the world as he does'. Imagining the self as other, however, shall not be confused with objectivity or emotional distance. The aim is not for a universal or feature-less person to look at the design, but to adopt diverse concrete positions and temporarily enact them as one's own. Waldenfels ${ }^{64}$ refers to this as Vervielfältigung des Ich - a multiplication of the self.

\section{Depth of Insight}

Natalia's interaction with the KMMA foregrounds many aspects the design team had incorporated successfully regarding functional and other-than-functional concerns. Stéphane understands many wheelchair-user requirements that go beyond what can be read in literature, guidelines, or regulations. Furthermore, he seems to be aware of his role as an architect in (disabled) people's lives and the fact that 'knowledge about the body in design needs to be coupled with an acceptance of "nonknowledge". ${ }^{65}$ Finnegan, ${ }^{66}$ for instance, points out that "there is a cultural component you won't get unless you talk to a disabled person'. Ultimately, our findings corroborate the idea that there are limits to empathy, especially in the absence of contextual information. ${ }^{67}$ 
Findings corroborate conclusions made by other scholars that empathy in design has its limits; there might be circumstances in which depth of insight is best achieved through actively engaging with end-users in order for designers to co-attend to functional and other-thanfunctional issues they cannot grasp on their own. The importance of spending time with those one might design for/with to go beyond the explicit or the assumed, as Stéphane stresses, is reflected in other studies as well; Buse et al., ${ }^{68}$ for instance, refer to an architect participating in their study arguing that 'reliance upon published information' is no substitute for spending 'time actually in a care home with people with dementia'.

\section{Limitations of the Study}

That Natalia is a wheelchair-user may be considered a strength in this study, but also a limitation. She brings in (embodied) knowledge (e.g. about what it means to be impaired and/or disabled by the built and social environment) that other researchers without personal connection to the research topic might lack (or may be able to empathise with at best). Yet, her deep involvement in the subject might have compromised her ability to fully silence her own biases and preconceptions. Moreover, interpretations and evaluations of the design outcome by other wheelchair-users might have produced different results.

\section{Concluding remarks}

This article started from the question how architects can design for imaginary users, specifically disabled users, as their perspectives have been considered particularly difficult to grasp within the design context. Whereas previous studies have examined the impact on design of architects 
being disabled themselves, in this article we focused on the impact of anticipating becoming disabled in the future. Through a case study of the KMMA, we examined how architect Stéphane Beel's anticipation of using a wheelchair shapes how and what he designs.

Our analysis suggests that Stéphane's ability to empathise in design may benefit from a certain flexibility in his use of embodied self, and moving between multiple positions. Thinking of the other as self may be an important aspect to reach affect (i.e. being motivated to empathise), rather than categorically maintaining affective distance between self and the (disabled) other. Contrarily, estranging the self in order to imagine the self as other may facilitate looking at designs through someone else's eyes, rather than invariably preserving one's own assumptions, values, and concerns. Empathy may thus involve closeness (to others), but also distance (to self). A difference shall be acknowledged, however, between looking through someone else's eyes in the context of an imaginative thought-exercise to estrange the self and the act of gaining knowledge from this estrangement about others. Likewise, for empathy to be successful in design, an awareness of bodily resonances might facilitate bridging the perceived gap between self and (disabled) other.

Additionally, it may be important to distinguish between empathy in the 'here and now' (in line with phenomenological understandings of empathy and the importance of bodily presence), and empathy delayed in time and triggered by a memory of a bodily encounter in the past (closer to the cognitive science scholars' understanding of empathy). The former is likely to be relevant in the field of co-design, the latter in design practices not engaging directly with endusers during the design process. Stéphane's encounter with Natalia may have deepened his understanding of the experience of using a wheelchair, and it may have implications for his future designs - in her absence. Future research could benefit from looking into the long-term 
consequences of their encounter; whether, or how, it will impact Stéphane's forthcoming projects, and how his idea to move from 'equal' to 'aesthetic' experience is materialised.

In building design since the end of the 20th century, embodied issues have been foregrounded in legislation relating to, for instance, issues of access and inclusive design. ${ }^{69}$ Addressing embodied issues related to disability solely to legislation presents a reduced and simplistic view of disability experience, ${ }^{70}$ and might explain why some design solutions aimed at solving accessibility problems are often experienced as 'isolated pieces of accessibility detached from its surroundings' ${ }^{71}$ Disentangling disability from legislation as sole connection in architecture, however, as has been the case with how Stéphane understands and interprets (wheelchair-)accessibility, shows potential in reaching design coherence, inclusion, as well as an aesthetically worthwhile design. Accessibility is more than what legislation can offer. Architecture in general, and access in particular, is 'imbued with meaning and impact on identity and comfort' ${ }^{72}$ Hence, disability in architectural design necessitates attending not to legislation alone, but being linked to the often overlooked social, embodied, narrative and experiential universe of disabled people. ${ }^{73}$ To integrate such experiential universe in design - or see a point in why architects should - we attend to the notion of empathy. As mentioned previously, one cannot empathise with legislation, with figures or technical information, but with people, their experiences and narratives.

Previous studies have shown that acquiring an impairment, and/or experiencing feeling disabled, may provide a privileged position by which to understand, and design for or with, disability ${ }^{74}$ Several architects experiencing disability show that they know certain design-related problems (because they have experienced them themselves); know how to solve them and what is possible (because they have been trained as architects); and are aware of what is at stake when 
designs do not respond to their needs or ways of being. ${ }^{75}$ Findings have shown that Stéphane may be in such position not with regard to embodying wheelchair-user experience, but with regard to being moved to act (i.e. being affected - a precondition to set empathy in motion), and with regard to being aware of his role as an architect and what is at stake for those he designs for. His design (approach) and mind-set show that architects do not necessarily need to embody experiences of using a wheelchair to be affected by them and incorporate (wheelchair)accessibility in an explicit and substantial way beyond regulatory prescriptions. Empathy does not equal (embodied) knowledge, as Stéphane himself points out, but empathy moves one to care and be willing to find ways to relate to the (disabled) other (e.g. discover resonances). Ultimately, we claim not that any architect would not be able to design for wheelchair-users in a qualitative way, but that not every architect is moved to do so - or is affected by a future possibility the way Stéphane is.

\section{Notes and References}

${ }^{1}$ In line with the social model of disability, we use 'impairment' to express an individual's constraint in a bodily function entailing a set of activity or social limitations, and 'disability' to express how societal discourses and practices result in 'disabling' a person in particular circumstances, e.g. by the built or social environment. Both terms are used depending on the meaning intended. See: Patrick Fougeyrollas, 'Documenting Environmental Factors for Preventing the Handicap Creation Process', Disability and Rehabilitation, 17.3-4 (1995), 145-53; Marno Retief and Rantoa Letšosa, 'Models of Disability', Theological Studies, 74.1 (2018), 1-8.

${ }^{2}$ Dana Cuff, Architecture: The Story of Practice (Cambridge: MIT Press, 1992); Rob Imrie, 'Architects' Conceptions of the Human Body', Environment and Planning D: Society and Space, 21.1 (2003), $47-65$. 
${ }^{3}$ Imrie, pp. 47-48.

${ }^{4}$ Dan Formosa, 'Six Real People', in Proceedings of the International Association of Societies of Design Research, 2009; Imrie.

${ }^{5}$ Joan Ablon, 'The Elephant Man as Self and Other', Social Science \& Medicine, 40.11 (1995), 1481-89; Bernhard Waldenfels, Der Stachel des Fremden (Frankfurt Am Main: Suhrkamp, 1990).

${ }^{6}$ Chris McGinley and Hua Dong, 'Designing with Information and Empathy', The Design Journal, 14.2 (2011), 187-206.

${ }^{7}$ Jane Fulton Suri, 'Communicating with Designers', Proceedings of the Human Factors and Ergonomics Society Annual Meeting, 44.38 (2000), 795-98 (pp. 795-96).

${ }^{8}$ Peter-Willem Vermeersch and Ann Heylighen, 'Rendering the Tacit Observable in the Learning Process of a Changing Body', in Proceedings of EKSIG 2013: Knowing Inside Out - Experiential Knowledge, Expertise and Connoisseurship, ed. by Nithikul Nimkulrat, Kristina Niedderer, and Mark Evans (Loughborough: Loughborough University, 2013), pp. 259-70.

${ }^{9}$ Natalia Pérez Liebergesell, Peter-Willem Vermeersch, and Ann Heylighen, 'Designing from a Disabled Body: The Case of Architect Marta Bordas Eddy', Multimodal Technologies and Interaction, 2.1 (2018), 4.

${ }^{10}$ Natalia Pérez Liebergesell, Peter-Willem Vermeersch, and Ann Heylighen, 'Through the Eyes of a Deaf Architect: Reconsidering Conventional Critiques of Vision-Centered Architecture', The Senses and Society, 14.1 (2019), 46-62.

${ }^{11}$ De Standaard, “t Groot lot De toevalstreffers, grote en kleine lotgevallen in het leven van Stéphane Beel / Architect', $2011<$ https://www.standaard.be/cnt/vl3g2vqh> [accessed 26 July 2019]; G Plets, 'Waterlanders / Stéphane Beel', De Standaard, 2011 <https://www.standaard.be/cnt/gcs37ohpr?articlehash=2FD720EDDECC96E9653886BCE3F998CD F86245A6A5A40A923B024152691B71820B470793A1D1C6F6676059A8C46213E0ABB89EAD3 68FBC08CB3E9AB0A3BE9BE6> [accessed 5 August 2019]. 
${ }^{12}$ After fieldwork was completed, the museum's name was changed to AfricaMuseum.

${ }^{13}$ Carol M. Davis, 'Empathy and Transcendence':, Topics in Geriatric Rehabilitation, 19.4 (2003), 265-

74; Carmel Flaskas, 'The Therapist's Imagination of Self in Relation to Clients', Australian and New Zealand Journal of Family Therapy (ANZJFT), 30.3 (2009), 147-59; Robert L. Katz, Empathy, Its Nature and Uses (London: Free Press of Glencoe, 1963).

${ }^{14}$ Inge Mette Kirkeby, 'Knowledge in the Making', Architectural Research Quarterly, 13.3-4 (2009), 307-13; Merlijn Kouprie and Froukje Sleeswijk Visser, 'A Framework for Empathy in Design', Journal of Engineering Design, 20.5 (2009), 437-48; David Weightman and Deana McDonagh, 'People Are Doing It for Themselves', in Proceedings of the International Conference on Designing Pleasurable Products and Interfaces (Pittsburgh, 2003), 34-39.

${ }^{15}$ George Robert Ellison Marshall and Claire Hooker, 'Empathy and Affect: What Can Empathied Bodies Do?', Medical Humanities, 42.2 (2016), 128-34.

${ }^{16}$ Ann Heylighen and Andy Dong, 'To Empathise or Not to Empathise?', Design Studies, 65 (2019), $107-24$.

${ }^{17}$ Paul Bloom, Against Empathy (New York: Ecco, 2016); Alvin I. Goldman, Joint Ventures (Oxford University Press, 2013).

${ }^{18}$ Dan Zahavi, Self and Other (Oxford: Oxford University Press, 2014).

${ }^{19}$ Ibid., p. 151.

${ }^{20}$ Bloom; Goldman.

${ }^{21}$ Karsten Stueber, 'Empathy', in The Stanford Encyclopedia of Philosophy, ed. by Edward N. Zalta (Stanford: Metaphysics Research Lab, Stanford University, 2019) <https://plato.stanford.edu/archives/fall2019/entries/empathy/> [accessed 10 July 2019].

${ }^{22}$ Kouprie and Visser, p. 447. 
${ }^{23}$ Linda Finlay, 'Reflexive Embodied Empathy', The Humanistic Psychologist, 33.4 (2005), 271-92 (p. 276).

${ }^{24}$ Bloom; Finlay; Maurice Merleau-Ponty, Phénomenologie de La Perception (London: Routledge \& Kegan Paul, 1962); Edith Stein, On the Problem of Empathy, 3rd edition (Washington DC: ICS Publications, 1989).

${ }^{25}$ Franz De Waal, The Age of Empathy (Crown Publishing, 2009).

${ }^{26}$ Ibid.

${ }^{27}$ Robert Yin, Case Study Research (Thousand Oaks: SAGE Publications, 2013).

${ }^{28}$ Ibid.

${ }^{29}$ In 2019 the project won the Publica Awards in two categories: Heritage and Architecture, and Public Award.

${ }^{30}$ Whereas our study purposefully touches upon a very specific aspect regarding empathy in design, the KMMA could further be studied in relation to how the museum's stand, the workers', the researchers', the stands from the diaspora, or the views from people from Central Africa come together from the perspective of empathy. Although we are aware of the project's larger context and political-historical importance, this has not been the focus of our analysis.

${ }^{31}$ Regie der Gebouwen, 'AfricaMuseum' < http://www.regiedergebouwen.be/nl/projects/africamuseum> [accessed 25 June 2019].

32 architectura.be, 'Groen Licht Voor Renovatie En Uitbreiding KMMA-Museum in Tervuren', 2010 <https://architectura.be/nl/nieuws/975/groen-licht-voor-renovatie-en-uitbreiding-kmma-museum-intervuren> [accessed 6 August 2019].

${ }^{33}$ Edward Venzon Cruz and Gina Higginbottom, 'The Use of Focused Ethnography in Nursing Research', Nurse Researcher, 20.4 (2013), 36-43; Hubert Knoblauch, 'Focused Ethnography', in Forum: Qualitative Social Research (Elsevier, 2005), VI, NO. 3, ART. 44; Janice Roper and Jill 
Shapira, Ethnography in Nursing Research (Thousand Oaks: Sage, 2000); Sarah Stahlke Wall, 'Focused Ethnography', in Forum: Qualitative Social Research, 2014, XVI.

${ }^{34}$ Knoblauch.

${ }^{35}$ A visit to the Raveelmuseum was proposed by Stéphane himself, and served to contrast previous insights gained at the KMMA, the main focus of our study. The director of the Raveelmuseum was present during our visit, and provided additional viewpoints.

${ }^{36}$ The Sage Encyclopedia of Qualitative Research Methods, ed. by Lisa M. Given (Los Angeles: Sage Publications, 2008).

${ }^{37}$ Bernadette Dierckx de Casterlé and others, 'QUAGOL: A Guide for Qualitative Data Analysis', International Journal of Nursing Studies, 49.3 (2012), 360-71.

${ }^{38}$ Devva Kasnitz and Russell Shuttleworth, 'Introduction: Anthropology in Disability Studies', Disability Studies Quarterly, 21.3 (2001); Karen Mogendorff, 'A closer look at 'wheelchair' ethnography', Social Research and Disability, (Abingdon: Routledge \& CRC Press, 2020), 50-63; Allison ReidCunningham, 'Anthropological Theories of Disability', Journal of Human Behaviour in the Social Environment, 19.1 (2009), 99-111.

${ }^{39}$ Benedicte Ingstad and Susan Reynolds Whyte, Disability and Culture (Berkeley: University of California Press, 1995); Robert F. Murphy, The Body Silent (London: Phoenix House, 1987); ReidCunningham.

${ }^{40}$ Roper and Shapira.

${ }^{41}$ Cruz and Higginbottom.

${ }^{42}$ Knoblauch; Marghalara Rashid, Vera Caine and Helly Goez, 'The Encounters and Challenges of Ethnography as a Methodology in Health Research', International Journal of Qualitative Methods, 14.5 (2015), 1-16. 
${ }^{43}$ Fernando Marquez Cecilia and Richard Lavene, 'Stéphane Beel 1992-2005. Estranged Familiarity', El Croquis, 125 (2006), 6-33; Plets.

${ }^{44}$ At the moment of the visit, Natalia had already studied the KMMA's floor plans. She was therefore familiar with a few basic features of the building's layout prior to the guided tour. She let Stéphane know that this was the case.

${ }^{45}$ Stein; Zahavi.

${ }^{46}$ Ruth Butler and Sophia Bowlby, 'Bodies and Spaces', Environment and Planning D: Society and Space, 15.4 (1997), 411-33.

${ }^{47}$ See Marshall and Hooker, p. 130, referencing Howard Spiro 'What Is Empathy and Can It Be Taught?', Annals of Internal Medicine, 116.10 (1992), 843-46 for a compelling example on how narrative can contribute to shift perspectives and humanise the other.

${ }^{48}$ Zahavi.

${ }^{49}$ Bloom; Goldman; Stueber.

${ }^{50}$ Gustaaf Bos and Doortje Kal, 'The Value of Inequality', Social Inclusion, 4.4 (2016), 129-39; Bernhard Waldenfels, 'Bodily Experience between Selfhood and Otherness', Phenomenology and the Cognitive Sciences, 3.3 (2004), 235-48.

${ }^{51}$ William Mazzarella, ‘Affect: What Is It Good For?', in Enchantments of Modernity, ed. by Saurabh Dube (London, New York, New Delhi: Routledge, 2010), 291-309 (p. 292).

${ }^{52}$ Robert F. Murphy, p. 86.

${ }^{53}$ Ray McDermott and Hervé Varenne, ‘Culture as Disability', Anthropology \& Education Quarterly, 26.3 (1995), 324-48; Irving Kenneth Zola, 'Self, Identity and the Naming Question', Social Science \& Medicine, 36.2 (1993), 167-73.

${ }^{54}$ Marshall and Hooker. 
${ }^{55}$ Heylighen and Dong.

${ }^{56}$ Bos and Kal, p. 135.

${ }^{57}$ Albert Shum, Kat Holmes, Kris Woolery, Margaret Price, Doug Kim, Elena Dvorkina, Derek DietrichMuller, Nathan Kile, Sarah Morris, Joyce Chou, Sogol Malekzadeh developed a document where these overlaps, or resonances, have been represented in drawings. See: https://www.microsoft.com/design/inclusive/.

${ }^{58}$ Tobin Siebers, Disability Theory (Ann Arbor: University of Michigan Press, 2008); John Swain and others, Disabling Barriers - Enabling Environments (London: SAGE, 2013).

${ }^{59}$ Marta Bordas Eddy, Sergio García Soler, Carlos Vidal Wagner, Miguel Usandizaga Calparsoro, and Natalia Pérez Liebergesell, Four Wheelchair-User Architects, ed. by Natalia Pérez Liebergesell (Barcelona: UPC Iniciativa Digital Politècnica and Gustavo Gili, 2017).

${ }^{60}$ Cuff; Imrie.

${ }^{61}$ Waldenfels, p. 8.

${ }^{62}$ Mark H. Davis, Empathy: A Social Psychological Approach (Boulder: Westview Press, 1996).

${ }^{63}$ Rosalind F. Dymond, 'A Scale for the Measurement of Empathic Ability', Journal of Consulting Psychology, 13.2 (1949), 127-33 (p. 127).

${ }^{64}$ Waldenfels, p. 67.

${ }^{65}$ Matthias Gross, Ignorance and Surprise, ed. by Don Ross (Cambridge, Mass: MIT Press, 2010), 5067; Kim Kullman, 'Prototyping Bodies', Design Studies, 47 (2016), 73-90 (p. 85).

${ }^{66}$ Shannon Finnegan referenced in Shaina Garfield 'When Empathy Isn't Enough', Frog Voices, 2018 $<$ https://medium.com/frog-voices/when-empathy-isnt-enough-87ccdb6ae072> [accessed 3 May 2019]. 
${ }^{67}$ Heylighen and Dong.

${ }^{68}$ Christina Buse, Sarah Nettleton, Daryl Martin, and Julia Twigg, 'Imagined Bodies: Architects and their Constructions of Later Life', Ageing and Society, 37.7 (2017), 1435-1457 (p. 1443).

${ }^{69}$ Rob Imrie and Rachael Luck, 'Designing Inclusive Environments: Rehabilitating the Body and the Relevance of Universal Design', Disability and Rehabilitation, 36.16 (2014), 1315-1319; Karen Soldatic, Hannah Morgan, and Alan Roulstone, Disability, Spaces and Places of Policy Exclusion (Abingdon: Routledge, 2014); referenced in Buse et al.

${ }^{70}$ Peter Hall and Rob Imrie, 'Architectural Practices and Disabling Design in the Built Environment', Environment and Planning B: Planning and Design, 26.3 (1999), 409-425; Janice Rieger and Megan Strickfaden, 'Taken for Granted: Relations Between Disability and Codes/Guidelines', Societies, 6.1 (2016), 6-17.

${ }^{71}$ Marta Bordas Eddy, 'Universal Accessibility: On the Need of an Empathy-Based Architecture' (PhD Thesis, Tampere University of Technology. School of Architecture. Housing Design. Vol. 26, 2017, 36).

${ }^{72}$ Melanie Lovatt, 'Becoming at Home in Residential Care for Older People: A Material Culture Perspective', Sociology of Health \& Illness, 40.2 (2018), 366-378, referenced in Sarah Nettleton, Christina Buse, and Daryl Martin, 'Envisioning Bodies and Architectures of Care: Reflections on Competition Designs for Older People', Journal of Aging Studies, 45 (2018), 54-62.

${ }^{73}$ Hua Dong, Chris McGinley, Farnaz Nickpour, and Abdusselam Selami Cifter, 'Designing for Designers: Insights into the Knowledge Users of Inclusive Design', Applied Ergonomics, 46 (2015), 284-291; McGinley and Dong.

${ }^{74}$ Natalia Pérez Liebergesell, 'The Difference Disability Makes: Learning about Interactions with Architectural Design from Four Architects Experiencing Disability' (PhD Thesis, KU Leuven, 2020).

${ }^{75}$ By way of example, we refer to a study that foregrounds how an architect not embodying wheelchairuser experience assessing wheelchair-accessibility explains to depend on her collaborator who is. 
Whereas the latter is able to assess accessibility at a glance, the former admits needing to 'look

more'. See: Natalia Pérez Liebergesell, Peter-Willem Vermeersch, and Ann Heylighen, 'Designing

from a Disabled Body: The Case of Architect Marta Bordas Eddy', Multimodal Technologies and

Interaction, 2.1 (2018), 4. 